QIJIS: Qudus International Journal of Islamic Studies

Volume 5, Issue 2, August 2017

\title{
BITCOIN: ISLAMIC LAW PERSPECTIVE
}

\author{
Luqman Nurhisam \\ UIN Sunan Kalijaga Yogyakarta, Indonesia \\ luckyman46@gmail.com
}

\begin{abstract}
In Indonesia, bitcoin is a form of digital currency (e-money) and means of payment transactions that have been used by some communities. It is necessary to get attention, especially from Bank Indonesia. Other than that, the supervision that was once fully done by the central bank of Bank Indonesia, is now taken over by OJK (Otoritas Jasa Keuangan). Thus, Bank Indonesia only has the authority to regulate and control the circulation of currency only. Since some of the tasks and authorities of Bank Indonesia were taken over by OJK (Otoritas Jasa Keuangan), many things have not been covered, such as the new phenomenon in the field of finance in terms of capital, investment, currency circulation, and others. In addition there is no legal umbrella against bitcoin, which is increasingly widespread transaction using bitcoin done in e-commerce transactions. So in terms of security also need to be questioned, therefore there needs to be regulation and supervision specifically against bitcoin, and society will not feel harmed. When viewed in the perspective of Islamic law, that relating to the issuance of money as a means of transactions in a country, is a matter protected by general rules in Islamic law. Therefore, the issuance of money and the determination of the amount is matters relating to the benefit of the people. Another aspect to consider in the use
\end{abstract}


of bitcoin is whether from the side of madharat isgreater or benefits taken if used as currency and tool transactions, even as a commodity though. So the focus in this research is the use of bitcoin as currency and transaction tool by using approach and study of Islamic law.

Keywords: bitcoin, e-money, e-commerce, currency

\section{A. Introduction}

Money is an integral part of everyday life. Some people argue that money is the blood of the economy, because in modern society today, economic mechanisms are based on economic activities such as buying and selling, leasing, import-export and so on, all of which require money as a means of transmitting to achieve A goal.

Today's growing age, economic activity from time to time also experienced many changes, such as what was not there now exist or vice versa. In the beginning before the creation of money as a tool in transactions, humans use the system of barter in trade. The economy of the barter system is an economic arena in which its transaction system, goods are exchanged for goods. Each item basically serves as money. When economic actors have found money as a means of transactions, then money has been agreed as a medium of exchange in the world economy. According to Dumairy, money as a medium of exchange must meet three conditions, which are generally accepted, serve as a means of payment, and valid in the sense of being recognized by the government (Dumairy, 1997).

In the modern economy, the role of money increases in harmony with increasing function. Money is no longer just a means of exchange, but it also functions as a unit of accounts, a store of value, and a standard of deferred payments, and even in the present Serves as a commodity item (Indra, 1992).

The payment system has changed over time, by looking at the evolutionary history of the payments system in the economy. The form of money continues to change along with the times. 
At one time, precious metals like gold were used as the primary means of payment. Further paper assets such as checks and banknotes are used as a means of payment and are considered money (Mishkin, 2010).

Nowadays, along with the development of science and technology, man managed to find electronic money (e-money). Intangible electronic money such as coins and paper money. Electronic money only in electronic form, for example is a debit card, smart card, and e-cash. Electronic money is more like a credit card, allowing consumers to buy goods and services directly and can transfer funds electronically from bank accounts to seller accounts. Electronic money can only be used in places that provide credit card payment systems (Mishkin, 2010).

The more sophisticated technology, it can affect the shape of the economic payment system that impacts on people's lives today. In modern times, people prefer to use electronic payment systems rather than using transactions with cash systems, because of the ease of electronic payment offered.

Looking at the phenomenon of today>s people who start a lot and choose to use electronic payment systems in transactions, can not be separated from the development of online buying and selling practices that become the lifestyle trend of today>s society. The practice of buying and selling by offering goods through television media, websites, and online stores is a form of convenience offered by the seller to consumers, to find and choose their needs. This is a form of new phenomenon that background of society life in various big city, because of time, career and busyness. Many of them no longer have time to go shopping. This happens because one consideration of the time required to shop, that will be more productive when used for work. While for the people in the village (who have been able to enjoy electricity and telephone facilities) are able to buy these items more influenced by the nature of consumptive. In addition to these considerations are many other reasons such as length of time to go to a place to shop, or because of traffic jams and so forth. 
Utilization of $W W W$ (World Wide Web) technology in conducting online trading transactions is increasing. This raises the amount of money circulation in cyberspace is large enough, given the absence of geographical restrictions. However, the current fiat currency system used as an online transaction is still limited by regulation rules of a country that have limitations in terms of privacy, transaction costs, inflation, and so on. From these limitations comes an idea from several people to create a new type of currency that is expected to overcome the problems of business-man especially online business players to be able to transact without any government intervention of his privacy. The idea of creating a new currency began to emerge based on cryptography.

Cryptography is a branch of essential science in the field of information security. Today, mathematicians and computer scientists have discovered another use of cryptography that has the potential to sustain people>s lives in the areas of buying and selling of digital currencies called cryptocurrency. Cryptocurrency is a digital currency that is not regulated by the government, and does not include the official currency. The concept of cryptocurrency is the basis for the birth of digital currency, which is currently famous for bitcoin currency as a means of payment like the currency in general.

Bitcoin is one of the few digital currencies that first appeared in 2009, introduced by Satoshi Nakamoto as a cryptography-based digital currency. Bitcoin is created by bitcoin tissues according to the needs and demands of bitcoin, systematically based on exact mathematical calculations.

Bitcoin is a payment network based on peer-to-peer technology and open source. Each bitcoin transaction is stored in the bitcoin database database. When a transaction with bitcoin occurs, the buyer and seller will automatically be recorded in the bitcoin database network (Darmawan, 2014). 
Phenomenon in the digital era as now, we are facilitated to get various services and facilities provided to enable the internet users to buy goods at online stores such as Bhinneka.com, Kaskus.com, Olx.co.id,Lazada.co.id and various Other e-commerce websites. In general, in our online buying and selling transactions facilitated in making payment transactions, via internet banking, mobile banking or by credit card. But with the presence of bitcoin as a digital currency, people can more easily transact than the payment transaction model as above.

Bitcoin offers easier payment methods without requiring a bank account, credit card or intermediary (account with Kaskus. com). Bitcoin is cash stored in a computer that can be used to replace cash in an online sale transaction. Unlike the other online currency associated with the bank and use a payment system such as paypal. Bitcoin is directly distributed between users without the necessary intermediaries.

But in Indonesia lately there are pros and cons against the use of bitcoin currency as a means of payment transactions. This is because bitcoin has not fulfilled some elements and criteria as currency applicable in Indonesia. As in UU No. 7 Year 2011 concerning "Mata Uang" Article 1 paragraph 1 stated that:

«Currency is money issued by the Unitary State of the Republic of Indonesia hereinafter referred to as Rupiah»

Bitcoin itself is not a currency issued by the state, but bitcoin is released through the cryptography system of computer networks. Then in addition to that in Article 1, paragraphs 6 and 7 mentioned that the raw materials used as money are paper and metal. Bitcoin itself is not a coin, paper, silver, or gold. Bitcoin is just a digital currency controlled by computer network software.

Bitcoin has several advantages and disadvantages when used as a currency, such as the absence of a legal umbrella that regulates the circulation of bitcoin currencies. In case of misuse of bitcoin such as theft, money laundering, fraud, and other crimes, no institution is responsible. 
Apart from that, when viewed from the other side, a money must be eligible, as Dumairy has mentioned that is, generally accepted, as a means of payment, and recognized by the government. Bitcoin itself, according to the authors have not fulfilled some of the money requirements, which there is no recognition from the government as a tool for payment, because bitcoin is something new by some people in Indonesia.

Seeing the incidents that arise in the community, many people use bitcoin as a means of payment, although they know that bitcoin does not qualify as a currency. Therefore, the authors are interested in reviewing these issues on the basis of consideration for the benefit and avoiding mafsadat against the practice of using bitcoin currencies.

In the case of bitcoin as a form of currency and means of payment transactions in the community, it is necessary to get special attention from Bank Indonesia. Other than that, the first supervision by the central bank, Bank Indonesia, is now taken over by OJK (Otoritas Jasa Keuangan). Thus, Bank Indonesia only has the authority to regulate and control the circulation of currency only. Since some of the tasks and authorities of Bank Indonesia were taken over by OJK (Otoritas Jasa Keuangan), many things have not been covered, such as the new phenomenon in the field of finance in terms of capital, investment, currency circulation, and others. In addition there is no legal umbrella against bitcoin, that is the increasingly widespread transactions that use bitcoin done by some people, and in terms of security also need to be questioned, therefore there should be rules and supervision specifically against bitcoin, so that people will not feel harmed.

Given the above phenomenon, the conception of bitcoin itself as a form of currency is still a lot of debate among experts, especially newly studied by some scholars, and bitcoin itself as a means of payment still requires consideration in terms of impact and benefits. Therefore, the authors are encouraged to review further using the approach and study of Islamic law. 


\section{B. Discussion}

\section{Currency Aspect}

Along with the progress of technology and information that has advanced to make transactions in the world of commerce is growing quite rapidly in general. Bitcoin, one form of currency that is recognized as one form of digital currency is no stranger to the world of online financial transactions in particular. Now, bitcoin has become one of the most practical and very fast payment transaction tools among the business community (merchant) or the user itself.

The choice of bitcoin as a means of payment of online financial transactions, making the economists especially Islamic jurists examine more seriously and deeply. Because bitcoin differs from previous things that one of the recognized forms of currency in Islam after the dinar (gold), dirham (silver) is fiat money. It even became a very long polemic and even today it is still a debate among the scholars who still maintain the classical argument.

Today the development of transactions using bitcoin has an impact or implication on its users, it can not be denied that transactions that use bitcoin provide fresh space that is profitable enough for merchants, and that it also provides flexibility for users or communities using bitcoin As a means of payment of their transactions. However, many impacts will be faced especially for the user or the community itself. That on the security side itself can not be accounted for, as it was known before that bitcoin is one form of unrecognized currency. That legally is not legally considered a currency.

In Indonesia alone the recognized currency is Rupiah (Rp), and it is associated with its own risk that all forms of use of bitcoin as a means of transactions and even commodities become the responsibility of each individual or community it self (Surat Edaran BI No. 16/06/Dkom). Indeed, the government does not prohibit the release of bitcoin, but which should be a warning to 
the community or users themselves that any risks to securityrelated uses are the responsibility of users. The government does not participate in it, so if at any time there are things related to bitcoin or criminal actions related to the circulation and use of bitcoin, it is clear that the government does not take part because it is not in authority.

In connection with the issuance of money as a means of transactions or means of payment in a country, that the issuance of money is a matter protected by general rules in Islamic law. Because the issuance of money and the determination of the amount is matters relating to the benefit of the people, while playing in the publishing of money will have an impact on the occurrence of madharat for the economy of the people (Jaribah, 2003). Among the forms of madharatare loss of confidence in the currency, the occurrence of forgery, the swelling of money and the fall in value (inflation), and the loss of people who have a fixed income due to it. Therefore jurists argue that the issuance of money is the authority of the state and is not allowed for the individual to do his own publishing especially let alone do things related to it so as not to cause damaging effects.

Imam Ahmad said, "It can not issue money but in state printing and with government permission. For, if broad societies are allowed to issue money, then they will do great harm." (AlQadhi, 1985)

Shaykh al-Islam Ibn Taimiyyah al-Jawziah said, "The government should print money for them (the people) as a substitute in their muamalat." (Ibnu Taimiyyah, 1995)

What is stipulated in Islamic jurisprudence about the publication of money by the government can be clearly observed in the economic jurisprudence of Umar ra. As a proof of that it is his attitude in a practical order, in which the khilafah state in his time did his good in the issuance of money. As he says, "I want to make a dirham out of camel's skin" (Abdul Jabbar, 1997). 
It also shows that Umar argues that the issuance of money is the authority of the authorities (ulil amri), because he said it with his status as khalifah for the Muslims. And ulil amri here means the authority assigned by priests to issue money in accordance with certain provisions, where the financial authorities based on their characteristics in this field, and in the perspective of commitment to Islamic values to limit the amount of money that fit the form The overall production of people and their level of development, and to push the pace of economic activity forward (Ahmad Majdzub, 1988).

\section{Aspects of Transactions}

The reason for the freedom to choose the means of exchange is that money is part of the trade and governed in the order of a common state. In the Qur'an, which regulates trade (QS. An-Nisa', 29):

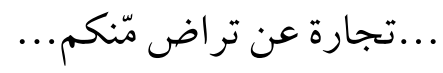

The meaning of the verse fragment is to trade according to the common good. On the basis that the position of the seller selling the merchandise as the initial foundation and the buyer issuing the means of payment to purchase the goods from the seller, lies in the agreement between the parties. If the merchant uses online financial transactions and payment instruments using digital currency, indirectly the buyer also agrees and agrees without notice. Due to in-running online transactions, the buyer is deemed to agree and agree if in the case when first buying a certain item on the online site to the merchant.

Referring to Bank Indonesia Regulation that in one point relating to the use of digital currency as a means of payment is directed to the merchant not to the issuer itself (PBINo. 11/12) $P B I / 2009)$. Therefore bitcoin as a means of payment includes rather than a means of payment directed to the trader rather than to the issuer rather than the bitcoin. 


\section{Bitcoin; Benefit or Madharat?}

Actually, there is a lot of potential to bitcoin itself, from profit, ease of transaction, and so forth. Whereas in every transaction muamalat which provides benefits for the parties concerned is one of the achievement of the goal of the benefit. More important, however, is that after reviewing the use of bitcoin primarily as a digital currency used as an online financial payment transaction is greater in madharatnya rather than utilization itself. So a lot of risk to its users, and this is not in accordance with the provisions of Islamic law that muamalat transactions that cause madharat should be abandoned(Washil and Azzam, 2009). Appropriate as set forth in one of fiqh rules namely:

$$
\text { الضّرر يز ال }
$$

Actually the concept of the rule implies that man should be kept away from idrār (acts of harm), both by himself and by others, and should not cause harm to others. All religious orders are established for the good of man, both in life and in the hereafter. Instead, all religious restrictions shall be stipulated solely to prevent the occurrence of various forms of mafsadat (destruction) in the life of the world and the hereafter (akhirat). This basic principle is the main foundation in every law stipulated in the Islamic law. Therefore, all forms of goodness and benefit must continue to be cultivated, while all forms of madharat and mafsadat must be avoided (Abdurrahman, 1976).

$$
\text { الضّرر يدفع بقدر الإمكان }
$$

The existence of obligation to avoid self will happiness or in other words do preventive action in order not to happen a madharat with all power and effort cultivated(Abdurrahman, 1976). Among the measures that can be taken to prevent of madharat are:

1. Promote the attitude of caution, especially in using something. Such as using bitcoin as a tool of transaction and commodity; 
2. Considering in terms of risks obtained, whether greater than the benefits generated, if large profits but greater risk of loss, then should be considered;

3. Any risk-related matters that would have adverse impacts should be abandoned;

4. Need to sort out in terms of transacting and investing in commodities, because the ability to choose the right also means being able to put something into place. So what is preached that kemaslahatan can be realized.

If at the same time faced with an option to reject the worship or gain the benefit, of course, which must take precedence is to reject conscience (Djazuli, 2011).

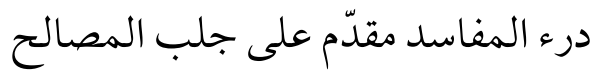

Because mafsadat can be expand and spread everywhere, so that will lead to greater damage. It is analogous to the prohibition of gambling, intoxicating drinks (khamr). Although in both there is benefit, but the danger to the damage is greater. As the word of Allah Swt (QS. Al-Baqarah: 219):

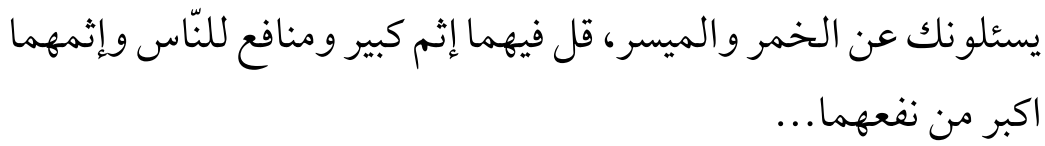

By rejecting conscience means also gaining the benefit. While the purpose of the Islamic law is to achieve the benefit in the world and in the hereafter. Actually in a matter that contains a madharatand contains also a benefit (maslahat), where between the two are really balanced, so difficult to divert, then based on the jurisprudence of the case must be rejected. In this case it is more reinforcing that preventing better worship, can be interpreted better to avoid syubhät than to do it, in accordance with as-Sunnah (Abdurrahman, 1976):

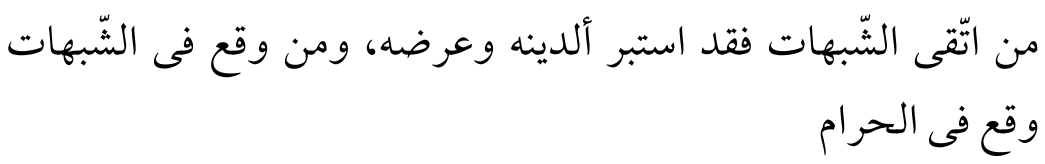


What is in the hadith is reinforced by later narrations of history by An-Nasai and at-Tirmidhi from Hasan bin Ali, namely (Djazuli, 2011):

$$
\text { دع ما يريبك إلى مالا يريبك }
$$

Benefits bring benefits to human life, while mafsadat leads to harmony for human life. The so-called maslahat has certain criteria among scholars, as described below (Djazuli, 2003):

1. The benefit must be measured in conformity with the maqashid as-syari'ah, kulli's arguments (general from alQur'an and as-Sunnah), the spirit of the teachings, and the rules of Islamic law;

2. The benefit must be convincing, in the sense that it must be based on accurate research, to no doubt;

3. That benefit should benefit most people, not a small percentage of people;

4. That benefit gives convenience, not brings trouble, in the sense that it can be done.

MUI (Majelis Ulama Indonesia) in the VII National Conference in 2005, provided the criteria of benefit in its decision No. 06/MUNAS/VII/MUI/10/2005 as follows:

1. Welfare according to Islamic law is the achievement of the purpose of Islamic law (maqāshid as-syari'ah), which is manifested in the form of maintaining the five primary needs (ad-dharūriyat al-khams), namely religion, soul, mind, wealth, and descent;

2. Welfare justified by Islamic law is the benefit that is not contrary to the texts;

3. The right to determine the benefit and whether something according to the Islamic law is an institution that has competence in the field of it and is done through ijtihad jama'i.

Departing from the above provisions that bitcoin is not one form of currency issued in a country, because based on the legality side of the positive law that is with the circular letter of Bank Indonesia stating that bitcoin is not recognized as one form of currency in circulation In the country. The aspect of the consideration from the side of madharat is greater than the 
benefits taken if used as a means of payment or transaction and even as a commodity though. Because of any risk to weaknesses in its security in case of misuse or criminal action against the use or access to bitcoin itself, especially if controlled by others who are not responsible, so if everything is to be borne by the community or bitcoin users. It certainly would be a greater danger risk for the community or bitcoin users.

The use of bitcoin as a means of payment transactions, especially on online financial transactions including syubhāt, and something that syubhāt it should be abandoned, because it does not bring benefits as well as the goal of the Islamic law that its own benefit can not be realized.

The development of technology and information much influence the development of legal fatwa which is urgent to be issued. Although the various fatwa law is not so sure mencover overall from various problems in the muamalattransaction. However, when viewed from various sides ie from the side of the rules of law that have been summarized by the previous scholars by looking at various similarities on <illat. An appropriate legal answer can be found to establish a law that has no clear provisions in both the Qur'an and the Sunnah.

\section{Conclusion}

This study discusses and explains the use of bitcoin as currency and payment transaction tool in terms of Islamic jurisprudence. So that can be drawn some conclusions related to the subject matter as follows:

1. The nature of bitcoin itself is one form of digital currency used as a payment transaction tool applied by the online business owners (merchants) contained in the Bank Indonesia Regulation concerning electronic money Number: 11/12/PBI/2009. Regarding the legality aspect, bitcoin is not one currency form issued in a country (currency), because based on the existence of Bank Indonesia Circular Letter No: 16/06/Dkom, which states that bitcoin is not recognized as one form of currency Circulated in the country. In the perspective of Islamic law relating to the issuance of money as a means of transactions or means of payment in a 
country, that the issuance of money is a matter protected by general rules in Islamic law. Because the issuance of money and the determination of the amount is matters relating to the benefit of the people, while playing in the publishing of money will have an impact on the occurrence of a great madharat for the economy of the people and the benefits. Among its madharat forms are the loss of confidence in the currency, the occurrence of counterfeiting, the swelling of the amount of money and the fall in value (inflation), as well as the loss of people who have a fixed income due to it. Therefore jurists argue that the issuance of money is the authority of the state and is not allowed for the individual to do his own publishing especially let alone do things related to it so as not to cause damaging effects. So it is clear that bitcoin is viewed from the perspective of Islamic law if from the side of currency issuance or currency in a country is not a state authority (ulil amri), and bitcoin includes the authority of an individual or merchant who uses it as a its digital currency.

2. Aspects to be considered is the side kemadharatannya greater than the benefits taken if used as currency and instrument of payment or transaction and even as a commodity though. Because of any risk to weaknesses in its security in case of misuse or criminal action against the use or access to bitcoin itself, especially if controlled by others who are not responsible, so if everything is to be borne by the community or bitcoin users. It certainly would be a greater danger risk for the community or bitcoin users. The use of bitcoin as a means of payment transactions, especially on online financial transactions including syubhāt, and something that syubhāt it should be abandoned, because it does not bring benefits as well as the goal of the Islamic law that its own benefit can not be realized. 


\section{REFERENCES}

Abdurrahman, A. Asjmuni. 1976.Qa'idah-Qaidah Fiqih. Cet. Ke-1. Jakarta: Bulan Bintang.

Ahmad, Ahmad Majdzub. 1409H.As-Siyasah An-Naqdiyah fi AlIqtishad Al-Islami.Cet. Ke-1. Riyadh: Dar Al-Liwa.

Al-Farra', Al-Qadhi Abu Ya'la Muhammad bin Husen. 1406H.AlAhkam As-Sulthaniyah, Beirut: Dar Al-Fikr.

Al-qur'an dan Terjemahnya Al-Jumanatul 'Ali. 2005. Bandung: CV Penerbit J-Art.

Haritsi, Jaribah bin Ahmad al-. 2003.Fikih Ekonomi Umar bin AlKhathab, Terjemahan Asmuni Solihan Zamakhsari, Al-Fiqh Al-Iqtishadi li Amri Mukminin Umar Ibnu Al-Khaththab. Jakarta: Khalifa.

As-Subhani, Abdul Jabbar bin Hamad. 1418H.An-Nuqud fi Al-Islam. Ed. Ke-12. Inggris: Majalah Al-Hikmah.

Darmawan, Indra. 1992.Pengantar Uang dan Perbankan. Jakarta: PT Rineka Cipta.

Darmawan, Oscar.2014.Bitcoin Mata Uang Digital Dunia. Jakarta: Jasakom.com.

Djazuli, A. 2003.Fiqh Siyasah. Cet. Ke-2. Jakarta: Prenada Media. . 2011. Kaidah-Kaidah Fikih. Jakarta: Kencana.

Dumairy.1997.Perekonomian Indonesia. Yogyakarta: BPFE.

Ibnu Taimiyyah.1416H.Majmu' al-Fatawa. 20 jilid. Madinah: Majma' Al-Malik Al -Fahdi li Thiba'ah Al-Mushaf AsySyarif.

Mishkin, Frederich S.2010. Ekonomi Uang, Perbankan, dan Pasar Keuangan Buku I. Alih bahasa Lana Soelistianingsih dan Beta Yulianita. Jakarta: Salemba Empat. 
Washil, Nashr Farid Muhammad dan Azzam, Abdul Aziz Muhammad.2009.Qawa'id Fiqhiyyah. Jakarta: Amzah.

Sekretariat MUI-2005, Himpunan Keputusan Musyawarah Nasional VII MUI tahun 2005.

Peraturan Bank Indonesia tentang uang elektronik Nomor: 11/12/ PBI/2009.

Surat Edaran Bank Indonesia Nomor: 16/06/Dkom. 